\title{
Cytogenetic study of Leptodactylus fuscus and L. latrans (Anura: Leptodactylidae) from the semiarid Brazilian Caatinga scrublands
}

Betejane de Oliveira1, Maysa S. S. Moraes², Daniel Dertônioº ${ }^{2}$ Renato G. Faria ${ }^{3}$, and Silmara M. Pantaleão ${ }^{2}$

${ }^{1}$ Programa de Pós-graduação em Ecologia e Conservação, Universidade Federal de Sergipe, 49100-000, São Cristóvão, SE, Brazil. E-mail: beteoliveira1@hotmail.com.

${ }^{2}$ Departamento de Biologia, Laboratório de Genética e Conservação de Recursos Naturais, Universidade Federal de Sergipe, 49100-000, São Cristóvão, SE, Brazil.

${ }^{3}$ Departamento de Biologia, Laboratório de Vertebrados - Herpetologia/Ictiologia, Universidade Federal de Sergipe, 49100-000, São Cristóvão, SE, Brazil.

\begin{abstract}
Cytogenetic study of Leptodactylus fuscus and L. latrans (Anura: Leptodactylidae) from the semiarid Brazilian Caatinga scrublands. Frogs in the family Leptodactylidae have diploid chromosome numbers ranging from $2 n=18$ to $2 n=26$, although there is a predominance of $2 \mathrm{n}=22$ karyotypes. In the present study, 52 specimens of Leptodactylus fuscus and Leptodactylus latrans were obtained from three municipalities (Carira, Poço Redondo, and Tobias Barreto) of the Brazilian state of Sergipe for karyotype analysis using conventional Giemsa staining techniques, and C- and Ag-NOR banding of the chromosomes obtained from the intestinal epithelium. The results of this study show that the individuals analyzed have highly similar karyotypes, with no evidence of any pronounced species-specific markers. However, some differences were observed in the chromosome morphology and C-bands in comparison with the karyotypes described previously for these species, which may represent intraspecific geographic variation in both taxa.
\end{abstract}

Keywords: amphibians, chromosomes, C-bands, Ag-NOR.

Received 1 August 2013.

Accepted 10 December 2013.

Distributed December 2013. 


\begin{abstract}
Resumo
Análise citogenética de Leptodactylus fuscus e L. latrans (Anura: Leptodactylidae) de áreas de Caatinga do Brasil. A família Leptodactylidae apresenta números diplóides que variam de $2 \mathrm{n}=18$ a $2 \mathrm{n}=26$, porém, na maioria dos gêneros descritos na literatura, há uma predominância de cariótipos com $2 \mathrm{n}=22$. Neste trabalho foram analisados citogeneticamente 52 exemplares de Leptodactylus fuscus e Leptodactylus latrans coletados pela primeira vez no estado de Sergipe, norte do Brasil, nos municípios de Carira, Poço Redondo e Tobias Barreto, por meio de técnicas de coloração convencional, Banda C e Ag-RON, empregadas em preparações do epitélio intestinal. Os dados mostraram que as espécies aqui analisadas apresentaram padrões cariotípicos muito similares, sem evidência de marcadores específicos das espécies. Contudo, algumas variações de morfologia cromossômica e bandas C observadas divergiram de cariótipos já descritos na literatura e podem indicar diferenças cromossômicas geográficas intraespecíficas para ambas as espécies.
\end{abstract}

Palavras-chave: anfíbios, cromossomos, Banda C, Ag-RON.

\section{Introduction}

The genus Leptodactylus Fitzinger, 1826 currently includes 89 frog species, which are found between southern North America and southern South America (Frost 2013). In Brazil, a total of 67 species are presently included in this genus (Pyron and Wiens 2011). Over the past few years, the systematics of the family Leptodactylidae has been reviewed by a number of authors (Hedges et al. 2008). For example, Adenomera, whose member species were originally included in Leptodactylus, was classified by Pyron and Wiens (2011) as a valid genus, a position supported by Frost (2013).

There is a predominance of $2 \mathrm{n}=22$ karyotypes in leptodactylid species. Approximately 40 species of Leptodactylus have been karyotyped (Zaracho and Hernando 2011), and most share very similar features, with the emphasis on metacentric and submetacentric chromosomes (Silva et al. 2004, Amaro-Ghilardi et al. 2006, Gazoni et al. 2012). A number of cytogenetic studies have reinforced the conservative nature of the karyotypes of the representatives of this genus (Denaro 1972, Bianchi et al. 1973, Bogart 1974, Silva et al. 2000, Amaro-Ghilardi et al. 2006, Arruda and Morielle-Versute 2008, Gazoni et al. 2012). The taxonomic position of a number of species groups is, however, still controversial (Angulo et al. 2003, Heyer 2005, Lavilla et al. 2010).

Based on a molecular study of the mitochondrial DNA of Leptodactylus fuscus, Camargo et al. (2006) confirmed that this taxon probably includes a number of cryptic species. These analyses also revealed the presence of a number of unrelated clades representing different, genetically isolated populations. Isozyme data from this same study confirmed the molecular analysis, indicating considerable differentiation in the two main clades, and the absence of gene flow between them.

The species now classified as Leptodactylus latrans (Steffen, 1815) has a long and controversial taxonomic history, beginning with the original description of Rana ocellata Linnaeus, 1758. Lavilla et al. (2010) concluded that this nomen is in fact a senior synonym of the Jamaican species Osteopilus brunneus (Gosse, 1851), whereas the taxon Leptodactylus ocellatus corresponds to Rana latrans Steffen, 1815. Given this, Leptodactylus latrans (Steffen, 1815) was revalidated as a new combination, and designated the new combination Osteopilus ocellata (Linnaeus, 1758), a senior synonym of Osteopilus brunneus (Gosse, 1851). 
Detailed data on the evolutionary relationships of amphibian populations from different regions may be especially important for the understanding of the history of Caatinga ecosystems, as well as the development of effective conservation strategies (Rodrigues 2005).

The species $L$. fuscus and L. latrans are found in the Caatinga scrublands of the Brazilian state of Sergipe, and little is known about the ecology or diversity of the populations that inhabit this semiarid biome. The present study provides a cytogenetic analysis of specimens of the two species from Sergipe, based on conventional staining and $\mathrm{C}$ - and Ag-NOR banding patterns.

\section{Materials and Methods}

The present study was based on the cytogenetic analysis of 14 specimens of L. fuscus and 38 specimens of L. latrans collected in the Brazilian state of Sergipe (Table 1, Figure 1), in the municipalities of Poço Redondo $\left(9^{\circ} 48^{\prime 2} 29.73^{\prime \prime} \quad\right.$ S, 37041'09.59" W), Carira $\left(10^{\circ} 22^{\prime} 54.18^{\prime \prime} \mathrm{S}, 37^{\circ} 41^{\prime} 06.33^{\prime \prime} \mathrm{W}\right)$, and Tobias Barreto (11 $\left.{ }^{\circ} 10^{\prime} 24.55^{\prime \prime} \mathrm{S}, 38^{\circ} 00^{\prime} 50.14^{\prime \prime} \mathrm{W}\right)$. All the specimens were deposited in the herpetological collection of the Laboratório de Herpetologia e Ictiologia, Departamento de Biologia, Universidade Federal de Sergipe, Brazil.
Metaphase chromosomes were obtained from the intestinal epithelium, following the protocol of Schmid (1978), with slight modifications. An average of five slides was prepared for each specimen, which were treated with traditional Giemsa staining, and $\mathrm{C}$ - and Ag-NOR banding.

The conventional staining was conducted using Giemsa stain diluted in $6.8 \mathrm{pH}$ phosphate buffer for 10 minutes. The $\mathrm{C}$ - and Ag-NOR banding used methods provided by Sumner (1972) and Howell and Black (1980), respectively. The metaphase spreads were analyzed by light microscopy, and photographed using a Moticam 2500 digital camera. Karyotypes were constructed and chromosome classification followed the nomenclature suggested by Green and Sessions (1991, 2007).

\section{Results}

All the specimens of both species have a karyotype of $2 \mathrm{n}=22$ chromosomes, and $\mathrm{FN}=$ 44 chromosome arms (Figures 2 and 3). The karyotype consists of seven pairs of large and medium chromosomes, and four pairs of small chromosomes. Chromosomes 1, 5, and 6 are metacentric, 2, 3, and 7 are submetacentric, and chromosome 4 is subtelocentric, while chromosomes 8, 9, 10, and 11 are either metacentric or submetacentric.

Table 1. Number of specimens of L. fuscus and L. latrans of different age-sex classes collected at the three study sites in Sergipe, northern Brazil. Legend: $J$ = juvenile, $F=$ adult female, $M=$ adult male.

\begin{tabular}{lcc}
\hline Species & Locality & Number of specimens by age/sex class \\
\hline Leptodactylus fuscus & Poço Redondo & $4 \mathrm{~J}$ \\
& Tobias Barreto & $4 \mathrm{~J}, 5 \mathrm{~F}, 1 \mathrm{M}$ \\
Leptodactylus latrans & Carira & $2 \mathrm{~J}, 8 \mathrm{~F}, 10 \mathrm{M}$ \\
& Poço Redondo & $7 \mathrm{~J}, 1 \mathrm{~F}, 2 \mathrm{M}$ \\
& Tobias Barreto & $1 \mathrm{~J}, 4 \mathrm{~F}, 3 \mathrm{M}$ \\
\hline
\end{tabular}




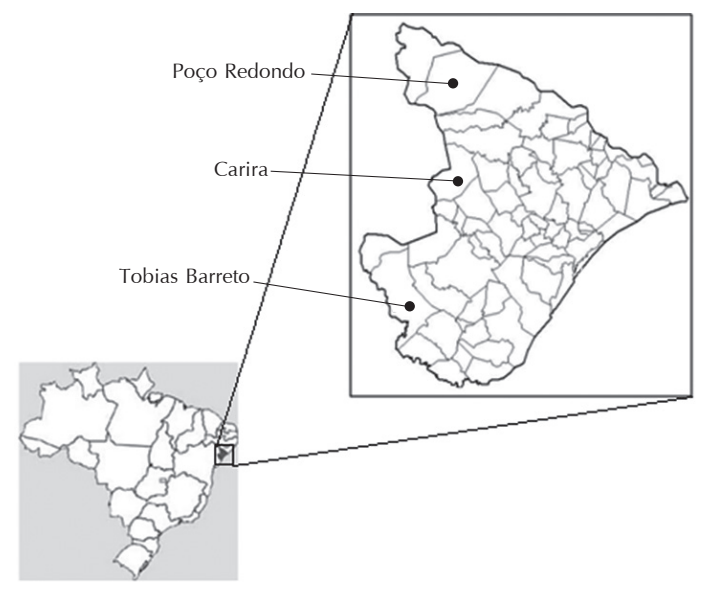

Figure 1. Location of the three municipalities in the Brazilian state of Sergipe (Carira, Poço Redondo, and Tobias Barreto), northern Brazil, where the Leptodactylus specimens were collected for the present study.

A secondary constriction in the terminal region of the short arm of both homologues of chromosome 8 was observed in L. fuscus. C-banding in this species revealed that the constitutive heterochromatin is found principally in the centromeric and/or pericentromeric regions of all the chromosomes (Figure 4). In some metaphases, however, blocs of heterochromatin of varying length were observed in the interstitial regions of the arms of some of the chromosomes of certain individuals. Chromosome 8 demonstrated C-positive heterochromatin in the proximal region of the short arms.

Centromeric/pericentromeric C-banding was observed in all the chromosomes of L. latrans, although C-positive telomeres were found only in the specimens from Tobias Barreto (Figure 5). Chromosomes 4, 7, 8, and 9 of the specimens from Poço Redondo and Tobias Barreto show pericentromeric C-positive blocs on the short arms. Chromosomes 10 and 11 were all similar in the specimens from Tobias Barreto, with subtle terminal markings on the short arms, while these marks were not apparent in the specimens from Poço Redondo. In general, the
L. latrans specimens from Tobias Barreto presented a more accentuated banding pattern, with technically better results than the specimens from other sites. It was not possible to obtain C-bands for the specimens from Carira.

In L. fuscus, Ag-NORs were observed in the interstitial region of the short arm of chromosome 8 , coinciding with the site of the secondary constriction (Figure 6), while in L. latrans, these bands were found in the terminal region of the short arms of this chromosome (Figures 7 and 8). In some cases, Ag-NORs were observed in association with one another (Figure 7, B.1).

\section{Discussion}

The present cytogenetic study was based on conventional staining and C- and Ag-NOR banding of specimens of L. fuscus and L. latrans from the semiarid Caatinga scrublands of the Brazilian state of Sergipe.

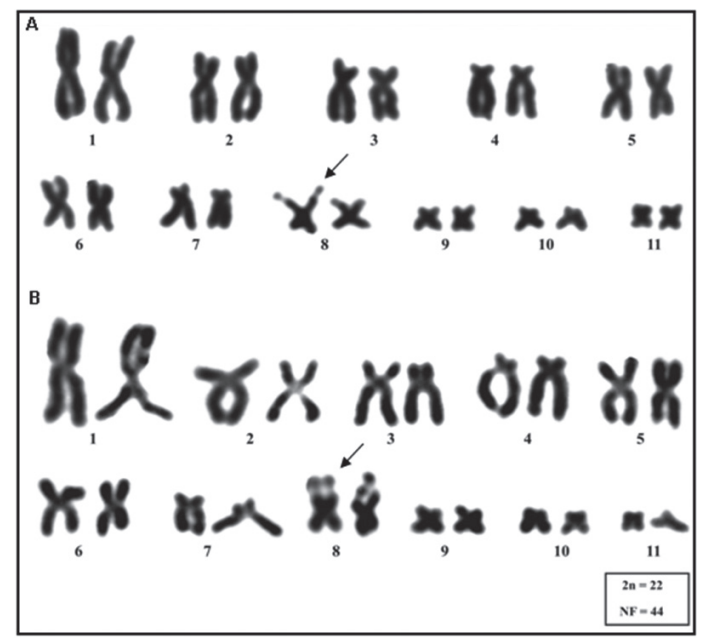

Figure 2. Karyograms for Leptodactylus fuscus based on conventional Giemsa staining. Specimens obtained in (A) Poço Redondo; (B) Tobias Barreto. The arrows indicate the location of the secondary constriction in chromosome 8 . Sex and voucher of specimens: (A) juvenile, FA5 and (B) adult female, FT2. 


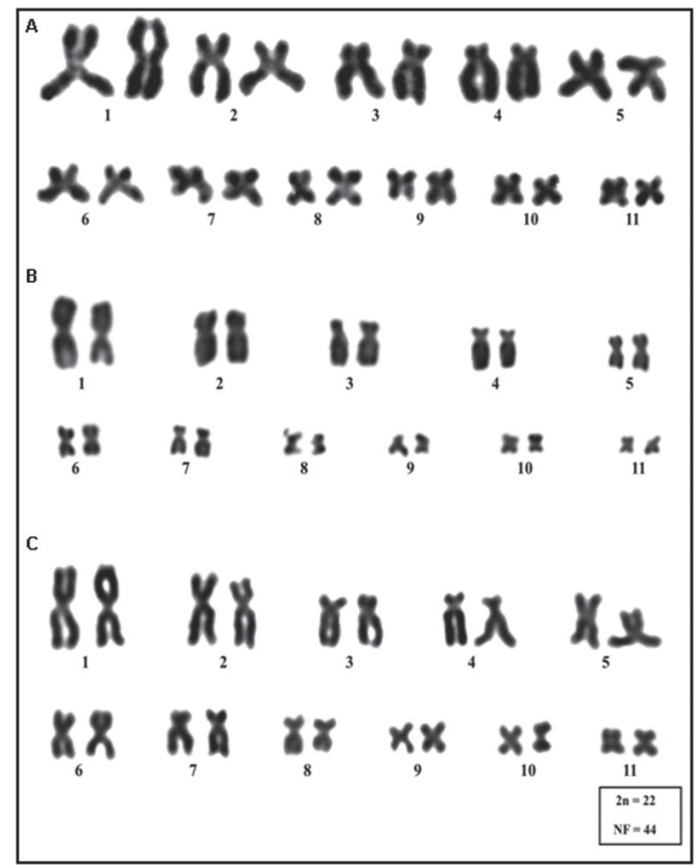

Figure 3. Karyograms of Leptodactylus latrans based on conventional Giemsa staining. Specimens obtained in (A) Carira; (B) Poço Redondo, and (C) Tobias Barreto. Sex and voucher of specimens: (A) adult male, OC15; (B) juvenile, OA1, and $(\mathbf{C})$ adult female, OT3.

While both the species analyzed in the present study had been previously karyotyped, beginning in the 1970s (Denaro 1972, Bianchi et al. 1973, Bogart 1974), and revised more recently (Amaro-Ghilardi et al. 2006, Silva et al. 2006), this is the first cytogenetic study of populations from the Caatinga, the least well protected Brazilian biome (Leal et al. 2005).

The diploid chromosome number of various leptodactylid species range from 18 to 26 , although there is a predominance of $2 \mathrm{n}=22$, which is almost exclusive to the genus Leptodactylus. Most Leptodactylus species have highly similar karyotypes, with a predominance of metacentric and submetacentric chromsomes

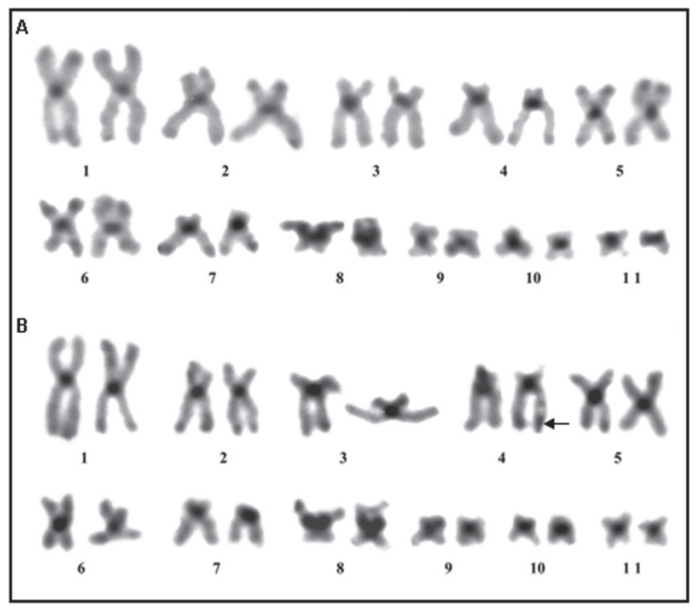

Figure 4. Distribution of C-bands in Leptodactylus fuscus specimens from (A) Poço Redondo and (B) Tobias Barreto. The arrow in (B) indicates variation in the distribution of interstitial heterochromatin between the homologues of chromosome 4. Sex and voucher of specimens: (A) juvenile, FA3 and (B) juvenile, FT2.

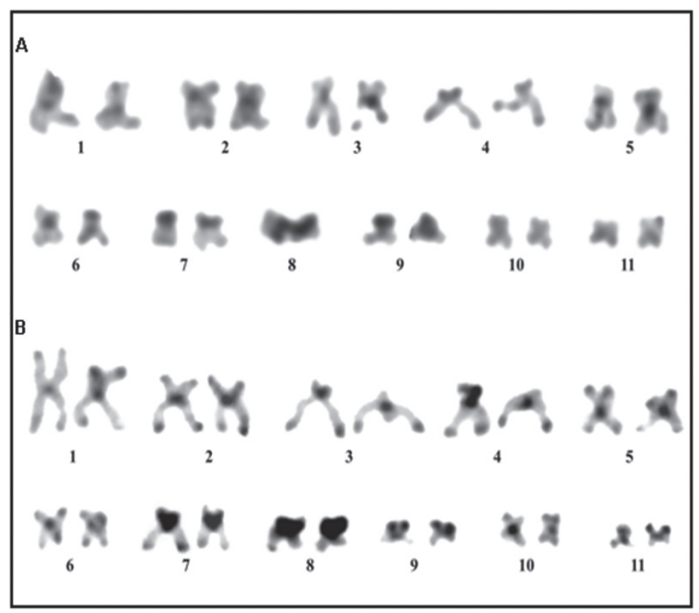

Figure 5. Distribution of C-bands in Leptodactylus latrans specimens from (A) Poço Redondo and (B) Tobias Barreto. Note the association between the chromosome 8 homologues in (A). Sex and voucher of specimens: (A) juvenile, OA5 and (B) adult female, OT2. 


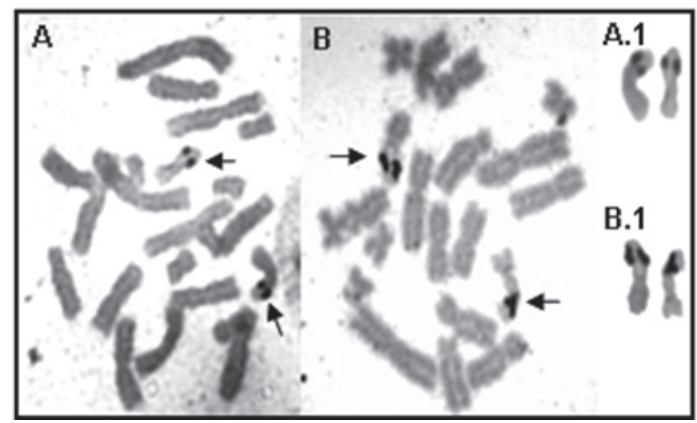

Figure 6. Metaphases following Ag-NOR banding in Leptodactylus fuscus specimens from (A) Poço Redondo and (B) Tobias Barreto. The arrows indicate the Ag-NORs. Highlighted: (A.1 and B.1) Pairs of chromosome 8 showing NORs. Sex and voucher of specimens: (A) juvenile, FA1 and (B) adult female, FT1.

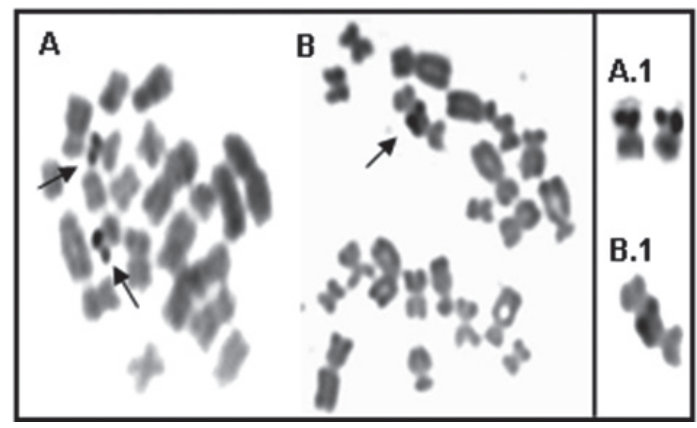

Figure 7. Metaphases of Leptodactylus latrans after AgNOR banding in specimens from (A) Poço Redondo and (B) Tobias Barreto. Highlighted: (A.1) NORs in the short arm of chromosome 8 and (B.1) presence of associated NORs. Sex and voucher of specimens: (A) juvenile, OA4 and (B) adult male, OT1.

(Beçak et al. 1970, Silva et al. 2000, 2004, 2006; Amaro-Ghilardi et al. 2004), as observed in the present study. There are some divergent species, however, such as Leptodactylus silvanimbus and Leptodactylus marmoratus (= Adenomera

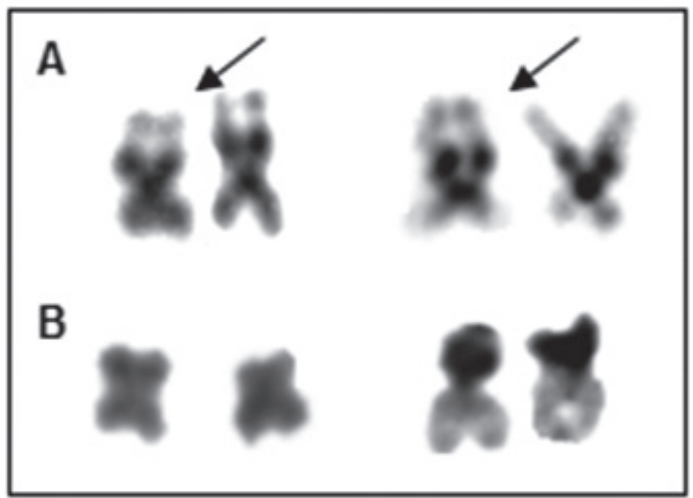

Figure 8. Secondary constriction located in the (A) intermediate region of the short arm of chromosome 8 in L. fuscus, and (B) terminal region of the short arm of chromosome 8 in $L$. latrans.

marmorata), which are $2 \mathrm{n}=24$ (Amaro-Ghilardi et al. 2006, Campos et al. 2009, Gazoni et al. 2012), and Leptodactylus hylaedactylus (= Adenomera hylaedactyla), which is $2 \mathrm{n}=26$ (Campos et al. 2009).

A marked secondary constriction was observed in the short arm of chromosome 8 in both populations of $L$. fuscus, coinciding with the Ag-NOR site. This structure was, however, not observed in L. latrans,

In closely-related species, the C-banding pattern may vary in terms of the quantity of heterochromatin, number of bands, and the location and density of the heterochromatin, which may represent an important cytotaxonomic parameter by reflecting possible chromosomal rearrangements arising during the evolution of the group (Sumner 1990). The C-banding is centromeric in both L. fuscus and L. latrans, although the constitutive heterochromatin was centro/pericentromeric in all the specimens of both species, as well as additional C-positive regions in some chromosomes, such as the telomeric or interstitial regions, or even the AgNOR sites. 
No between-population differences were found in the C-banding of L. fuscus. C-positive telomeric regions were not observed in specimens of this species from Rio Claro in the southeastern Brazilian state of São Paulo (Silva et al. 2000). The homologues of chromosome 4 in the specimens from Tobias Barreto showed varying quantities of heterochromatin, which is typical of C-banding patterns. Such differences in the quantity and distribution of the heterochromatin have been important for the definition of speciesand subspecies-level differentiation in amphibians (Matsui et al. 1985). The heterochromatin distribution pattern observed in the specimens of L. latrans from Tobias Barreto was similar to that described by Amaro-Ghilardi et al. (2006) in specimens from Igarassu (Pernambuco, Brazil), which presented C-positive pericentromeric blocs on the short arms of chromosomes 4, 7 and 8 .

Studies of other L. latrans populations have revealed three distinct patterns in the distribution of the heterochromatin, which have not been specifically attributed to distinct taxa, but rather geographic variation in the karyotype or possibly indicative of a species complex, given observed individual variation in external morphology, bioacoustics, and habitat use (Silva et al. 2000, 2006).

Most Leptodactylus species have a single pair of NORs, generally located on chromosome 8, albeit in distinct parts of this chromosome (Lisanti et al. 1990, Silva et al. 2004, AmaroGhilardi et al. 2006). However, in some species, the NORs are located on chromosomes 3 or 4 , while L. marmoratus (= Adenomera marmorata) presents multiple NORs on the telocentric chromosomes 6 and 8 (Gazoni et al. 2012).

In the L. fuscus specimens analyzed in the present study, the NORs were observed in the interstitial region of the short arm of chromosome 8, coinciding with the site of the secondary constriction. In L. latrans, NORs were also observed in the terminal region of chromosome 8 , with a small euchromatic region at the end of the constriction.
All the specimens of L. fuscus and L. latrans analyzed here presented karyotypes highly similar to those described in the literature, except for some variation in the C-banding. It seems likely that new patterns will be discovered as further cytogenetic studies are performed on species of Leptodactylus, principally those using more refined techniques capable of identifying species-specific chromosome markers, as well as a wider range of specimens representing new sites in Sergipe and other regions of the Caatinga. Such data should provide additional insights in the evolutionary relationships within the group.

The leptodactylid frogs Leptodactylus fuscus and $L$. latrans analyzed in the present study both have a $2 n=22$ diploid chromosome number, with metacentric, submetacentric, and subtelocentric chromosomes. No marked differentiation was found in the karyotypes of either species. In addition, no between-population variation in the C-banding pattern was observed in L. fuscus, whereas some differences were found in the banding pattern of the L. latrans specimens from Tobias Barreto and Poço Redondo, as well as between these specimens and those described from other sites, which indicates that this widelydistributed species may either represent part of a species complex or an ongoing radiation.

\section{Acknowledgments}

We are grateful to the Brazilian Higher Education Training Program (CAPES) for financial support, the Biodiversity Information and Authorization System (SISBio) of the Brazilian government for authorizing the collection of specimens, and the Sergipe state ministry for the environment and natural resources (SEMARH) for logistic support. We are extremely grateful to Dra. Sanae Kasahara for her critical reading of the manuscript, and Simone Gruber and Thiago Gazoni for their assistance in the laboratory, as well as Anthony Ferreira and the family of Mr. "Didi" for their help with the collection of specimens. 


\section{References}

Amaro-Ghilardi, R. C., M. T. Rodrigues, and Y. YonenagaYassuda. 2004. Chromosomal studies after differential staining and fluorescence in situ hybridization using telomeric probe in three Leptodactylus species (Leptodactylidae, Anura). Caryologia 57: 53-65.

Amaro-Ghilardi, R. C., G. Skuk, R. O. de Sá, M. T. Rodrigues, and Y. Yonenaga-Yassuda. 2006. Karyotypes of eight species of Leptodactylus (Anura, Leptodactylidae), with a description of a new karyotype for the genus. Phyllomedusa 5: 119-133.

Angulo, A., R. B. Cocroft, and S. Reichle. 2003. Species identity in the genus Adenomera (Anura, Leptodactylidae) in southeastern Peru. Herpetologica 59: 490-504.

Arruda, M. P. and E. Morielle-Versute. 2008. Cytogenetic and random amplified polymorphic DNA analysis of Leptodactylus species from rural and urban environments (Anura, Amphibia). Genetics and Molecular Research 7: 161-17.

Beçak, M. L., L. Denaro, and W. Beçak. 1970. Polyploidy and mechanisms of karyotypic diversification in Amphibia. Cytogenetics 9: 225-238.

Bianchi, N. O., M. Bianchi, and L. Vidal-Rioja. 1973. Heterochromatin late replication and secondary constrictions in the chromosome complement of Leptodactylus ocellatus. Journals of Gerontology. Series A: Biological Sciences and Medical Sciences 26: $397-$ 403

Bogart, J. P. 1974. A karyosystematic study of frogs in the genus Leptodactylus (Anura: Leptodactylidae). Copeia 1974: 728-737.

Camargo, A., R. O. de Sá, and W. R. Heyer. 2006. Phylogenetic analyses of mtDNA sequences reveal three cryptic lineages in the widespread neotropical frog Leptodactylus fuscus (Schneider, 1799) (Anura, Leptodactylidae). Biological Journal of the Linnean Society 87: 325-341.

Campos, J. R. C., F. Ananias, C. A. Brasileiro, M. Yamamoto, C. F. B. Haddad, and S. Kasahara. 2009. Chromosome evolution in three Brazilian Leptodactylus species (Anura, Leptodactylidae), with phylogenetic considerations. Hereditas 146: 104-111.

Denaro, L. 1972. Karyotypes of Leptodactylidae anurans. Journal Herpetology 6: 71-74.

Frost, D. R. 2013. Amphibian Species of the World: an Online Reference. Version 5.6 (9 January 2013). Electronic Database accessible at http://research.amnh.
org/herpetology/amphibia/American Museum of Natural History, New York, USA. Captured on 25 May 2013.

Gazoni, T., S. L. Gruber, A. P. Z. Silva, O. G. S. Araújo, H. Narimatsu, C. Strüssmann, C. F. B. Haddad, and S. Kasahara. 2012. Cytogenetic analyses of eight species in the genus Leptodactylus Fitzinger, 1843 (Amphibia, Anura, Leptodactylidae), including a new diploid number and a karyotype with multiple translocations. BMC Genetics 13: 109.

Green, D. M. and S. K. Sessions. 1991. Nomenclature for chromosomes. Pp. 431-432 in D. M. Green and S. K. Sessions (eds.), Amphibian Cytogenetics and Evolution. San Diego. Academic Press.

Green, D. M. and S. K. Sessions. 2007. Karyology and cytogenetics. Pp. 2757-2842 in H. Heatwole (ed.), Amphibian Biology, vol. 7. Chipping Norton. Surrey Beatty \& Sons.

Hedges, S. B., W. E. Duellman, and M. P. Heinicke. 2008. New World direct-developing frogs (Anura: Terrarana): molecular phylogeny, classification, biogeography, and conservation. Zootaxa 1737: 1-182.

Heyer, W. R. 2005. Variation and taxonomic clarification of the large species of the Leptodactylus pentadactylus species group (Amphibia: Leptodactylidae) from Middle America, northern South America, and Amazonia. Arquivos de Zoologia 37: 269-348.

Howell, W. M. and D. A. Black. 1980. Controlled silverstaining of nucleolus organizer regions with a protective colloidal developer: 1-step method. Experientia 36: 1014-1015.

Lavilla, E. O., J. A. Langone, U. Caramaschi, W. R. Heyer, and R. O. de Sá. 2010. The identification of Rana ocellata Linnaeus, 1758. Nomenclatural impact on the species currently known as Leptodactylus ocellatus (Leptodactylidae) and Osteopilus brunneus (Gosse, 1851) (Hylidae). Zootaxa 2346: 1-16.

Leal, I. R., J. M. C. Silva, M. Tabarelli, and T. E. Lacher Jr. 2005. Mudando o curso da conservação da biodiversidade na Caatinga do Nordeste do Brasil. Megadiversidade 1: 139-146.

Lisanti, J. A., G. D. de Barale, E. Oinns-Senn, and J. C. Stockert. 1990. A specimen of Leptodactylus ocellatus (Anura, Leptodactulidae) heterozygous for a deletion of the nucleolar organizing region. Comunicaciones Biologicas 9: 127-31.

Matsui, M., T. Seto, Y. Kohsaka, and L. J. Borkin. 1985. Bearing of chromosome C-banding patterns on the classification of Eurasian toads of the Bufo bufo complex. Amphibia-Reptilia 6: 24-34. 
Pyron, R. A. and J. J. Wiens. 2011. A large-scale phylogeny of Amphibia including over 2800 species, and a revised classification of extant frogs, salamanders, and caecilians. Molecular Phylogenetics and Evolution 61: 543-583.

Rodrigues, M. T. 2005. Herpetofauna da Caatinga. Pp 181236 in I. R. Leal, M. Tabarelli, and J. M. C. Silva (eds.), Ecologia e Conservação da Caatinga, $2^{\text {nd }}$ ed. Recife. Editora Universitária da UFPE.

Schmid, M. 1978. Chromosome banding in Amphibia. I. Constitutive heterochromatin and nucleolus organizer regions in Bufo and Hyla. Chromosoma 66: 361-368.

Silva, A. P., C. F. B. Haddad, and S. Kasahara. 2000. Chromosomal studies on five species of the genus Leptodactylus Fitzinger, 1826 (Amphibia, Anura) using differential staining. Cytobios 103: 25-38.

Silva, A. P. Z., P. C. A. Garcia, V. G. Martins, B. Maurício, and S. Kasahara. 2004 Chromosomal and molecular analyses of Leptodactylus gracilis gracilis, L. gracilis delattini, and L. plaumanni (Anura, Leptodactylidae): taxonomic implications. Amphibia-Reptilia 25: 185196.

Silva, A. P. Z., C. F. B. Haddad, G. G. Galassi, and S. Kasahara. 2006. Multiple nucleolus organizer regions in Leptodactylus mystacinus (Amphibia, Anura) and comments on its systematic position in the L. fuscus group based on cytogenetic and molecular analyses. Genetica 127: 35-44.

Sumner, A. T. 1972. A simple technique for demonstrating centromeric heterochromatin. Experimental Cell Research 75: 304-306.

Sumner, A. T. 1990. C-banding and related methods. Pp. 39-69 in A.T. Sumner (ed.), Chromosome Banding. London. Unwin Hyman Ed.

Zaracho, V. H. and A. B. Hernando. 2011. The karyotype of Adenomera diptyx (Boettger, 1885) (Anura, Leptodactylidae) from northeastern Argentina. Genetics and Molecular Biology 34: 84-87. 